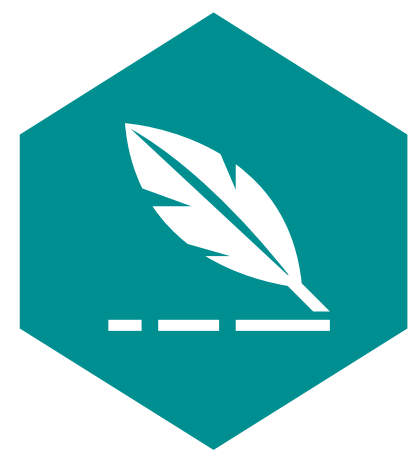

The International Journal of

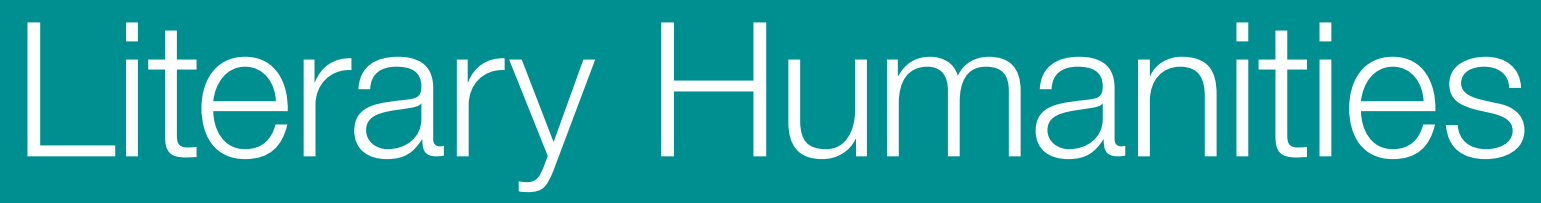

Representation of Ethical Values for Nature Sustainability

Ecological Wisdom in Novels by Indonesian Women 


\section{EDITOR}

Asunción López-Varela, Universidad Complutense de Madrid, Spain

ACTING DIRECTOR OF PUBLISHING

Jeremy Boehme, Common Ground Research Networks, USA

MANAGING EDITOR

Megan Donnan, Common Ground Research Networks, USA

\section{ADVISORY BOARD}

The New Directions in the Humanities Research Network recognizes the contribution of many in the evolution of the Research Network. The principal role of the Advisory Board has been, and is, to drive the overall intellectual direction of the Research Network. A full list of members can be found at https://thehumanities.com/about/advisory-board

\section{PEER REVIEW}

Articles published in The International Journal of Literary Humanities are peer reviewed using a two-way anonymous peer review model. Reviewers are active participants of the New Directions in the Humanities Research Network or a thematically related Research Network. The publisher, editors, reviewers, and authors all agree upon the following standards of expected ethical behavior, which are based on the Committee on Publication Ethics (COPE) Codes of Conduct and Best Practice Guidelines. More information can be found at: https://thehumanities.com/journals/model.

\section{ARTICLE SUBMISSION}

The International Journal of Literary Humanities

publishes biannually (June, December).

To find out more about the submission process, please visit

https://thehumanities.com/journals/call-for-papers.

\section{THE INTERNATIONAL JOURNAL OF}

LITERARY HUMANITIES

https://thehumanities.com

ISSN: 2327-7912 (Print)

ISSN: 2327-8676 (Online)

https://doi.org/10.18848/2327-7912/CGP (Journal)

First published by Common Ground Research Networks in 2021 University of Illinois Research Park

60 Hazelwood Drive

Champaign, IL 61820 USA

https://cgnetworks.org

The International Journal of Literary Humanities

is a peer-reviewed, scholarly journal.

\section{COPYRIGHT}

(C) 2021 (individual papers), the author(s)

(C) 2021 (selection and editorial matter),

Common Ground Research Networks

All rights reserved. Apart from fair dealing for the purposes of study, research, criticism, or review, as permitted under the applicable copyright legislation, no part of this work may be reproduced by any process without written permission from the publisher. For permissions and other inquiries, please contact cgscholar.com/cg_support.

\section{ABSTRACTING AND INDEXING}

For a full list of databases in which this journal is indexed, please visit https://thehumanities.com/journals/collection.

\section{RESEARCH NETWORK MEMBERSHIP}

Authors in The International Journal of Literary Humanities are members of the New Directions in the Humanities Research Network or a thematically related Research Network. Members receive access to journal content. To find out more, please visit https://thehumanities.com/about/become-a-member.

\section{SUBSCRIPTIONS}

The International Journal of Literary Humanities is available in electronic and print formats. Subscribe to gain access to content from the current year and the entire backlist. Contact us at cgscholar.com/cg_support.

\section{ORDERING}

Single articles and issues are available from the journal bookstore at https://cgscholar.com/bookstore.

\section{HYBRID OPEN ACCESS}

The International Journal of Literary Humanities is Hybrid Open Access, meaning authors can choose to make their articles open access. This allows their work to reach an even wider audience, broadening the dissemination of their research. To find out more, please visit https://thehumanities.com/journals/hybrid-open-access.

\section{DISCLAIMER}

The authors, editors, and publisher will not accept any legal responsibility for any errors or omissions that may have been made in this publication. The publisher makes no warranty, express or implied, with respect to the material contained herein. 


\title{
Representation of Ethical Values for Nature Sustainability: Ecological Wisdom in Novels by Indonesian Women
}

\author{
Sultan, ${ }^{1}$ Universitas Negeri Makassar, Indonesia \\ Anshari, Universitas Negeri Makassar, Indonesia
}

\begin{abstract}
It is imperative to investigate women writers' perspectives through their literary works to discover their beliefs and views on environmental issues. Environmental wisdom represented in literary works by Indonesian women have never been studied. This article aimed to examine environmental ethics represented in three novels authored by Indonesian women. The selected novels that were published in the last ten years served as the sources of the research data. A qualitative-interpretative research approach was utilized to reveal environmental ethics represented in the novels. The results of the analysis suggest that the novels depict various environmental ethics that reflect the environmental knowledge, attitudes, integrity, and awareness of the Indonesian women. This finding implies a shift in the ideology of women writers in developing countries, especially in the environmental aspects of the novels produced.
\end{abstract}

Keywords: Ecoritics, Ecological Wisdom, Ethical Values, Indonesian Novel, Women Writer

\section{Introduction}

$\mathrm{E}$ cocritics is one of the fast-developing literary schools of thought today. Literary studies with an eco-criticism approach have been carried out in various countries, examining a variety of topics including criticism of human economic exploitation of the environment, development capitalism, the idea of environmental preservation, the interrelationship between the human and nonhuman worlds, and local culture-based environmental ethics (Lehnen 2020; Forns-Broggi 2012; Lu 2017; Ahmed and Hashim 2015; Barker 2007; Finch-Race and Weber 2015; Tait 2018). The development of this literary subject is based on the fact that ecological life has been increasingly threatened as a result of human exploitative behavior. This study appears as a reaction to the anthropocentric attitude of dominating nature (Mishra 2016).

Ecocritics is a field of literary study that describes the way humans establish a relationship with the physical environment (Garrard 2004; Volkmann et al. 2010) and has an enlightenment vision to elevate the dignity of human beings as intelligent creatures in mastery of the universe through the representation of its relationship in literary texts (Egan 2015). Ecocritical literature attempts to offer a viewpoint of the ecological role for the survival of life by exploring the ways humans imagine and describe relationships with the environment in all fields of cultural production. Ecocritical literary works unravel the expression of romanticism and harmony with nature, expose the suffering and fear of disaster, and explore the potential to lose the balance with ecological life (Cohen 2004). It also demonstrates how literature contributes to the articulation, interpretation, and transformation in the relationship between nature and culture (Erik Larsen 2007). As a literary study, eco-criticism has an important meaning in building human awareness about interdependence with nature, so they can act accordingly and wisely in interacting with the nature.

Research employing an ecocritical approach to examining Indonesian literary works is still relatively new and the number of studies is quite limited. Retnowati, Ernawati, and Akun (2018), Sukmawan (2018), and Lustyantie, Setyowati, and Rohman (2019) studied eco-criticism

\footnotetext{
${ }^{1}$ Corresponding Author: Sultan, Jalan Daeng Tata Raya, Department of Indonesian Language and Literature,

Universitas Negeri Makassar, Makassar, South Sulawesi, 90224, Indonesia. email: sultan@unm.ac.id
} 
in oral literature. Ahmadi et al. (2019) examined the ecopsychology of Indonesian novels. Wiyatmi (2017) revealed the conquest and care character of nature conservation in Amba's Novel. The study of Amba illustrates the transformation of a remote and arid island from an island of exile for political prisoners into an island that invites visitors to explore, exploit and preserve its natural wealth. Unlike the previous studies, this study aimed to reveal the representation of environmental ethics for nature conservation in novels authored by three Indonesian women. This study was based on the argumentation of Salisu Barau, Stringer, and Adamu (2016) which suggests that creative literary works are a fine source for the transmitting of environmental ethics to citizens.

It is important to examine the literary works of Indonesian women to uncover the manifestations of their knowledge, attitudes, and perspectives on environmental issues. Jackson (1993) suggests that women have a special and close relationship with nature; they tend to be altruistic and caring about environmental management. Nature and women are two entities that are frequently made as the object of exploitation (Hooti and Ashrafian 2014; Wylie 2014). The same fate experienced by women and nature as objects of exploitation can be a determinant factor in influencing the attitudes of women authors in their works on ecocritical themes. The findings of Bhutia and Liaroku (2018) show that women are more environmentally friendly and express their readiness and willingness to participate as policy makers, take roles as leaders in the environmental field, and show confidence in trustworthy abilities and sensitivity. This will inspire their way of thinking and authorship so as to bring influence to the resulting literary works. Therefore, women's perspectives and ways of expressing ideas in their resulting literary works are interesting topics that need to be discussed.

Indonesian women show rapid development through themes in their literary works. They have been involved in totality in contemporary social and political problems (Hatley 1999). The paradigm shift in the work of women writers is based on the profile of a new generation of Indonesian women, who are educated, mobile, cosmopolitan, and involved in political activities. Michalik (2015) found that Indonesian women filmmakers created different identities and introduced various female characters into their work. Indonesian women filmmakers express problems and topics in their own way. Such a woman's character shifts the new values and roles of Indonesian culture through literary works, including ecological issues. In line with that concept, Barry and Grady (2019) state that feminism strengthens political ecology in the management of resources, ecosystem protection, and livelihoods that depend on ecosystems. In Indonesian contexts, Jurr s (2018) who studied Setu Legi, one of the country's contemporary works of art, identified the interdependence of nature, social, and environmental politics. However, the paradigm shift of Indonesian women in environmental-themed novels has not been revealed until now.

Previous studies have shown that women have different priorities compared to men in dealing with environmental problems. Women express higher concern and are more likely to act "pro-environment" than men (Ramstetter and Habersack 2019). In the political field, the findings of Ramstetter and Habersack (2019) show that women political figures are significantly more supportive of environmental regulation than male legislators. Girls who study environmental education show better basic attitudes toward the environment (Braun, Cottrell, and Dierkes 2018). Cultural ecofeminism holds that there is an innate relationship between women and nature with a tendency for them to live in harmony, care for each other, and recognize this special connection (Vakoch 2012). These studies confirm that women have a more positive attitude toward the environment compared to men. The characteristics of women in relation to the environment that has been described can have implications in the creative process. The knowledge, beliefs, and attitudes of women toward the environment influence the creation of their literary works. However, this topic has not been explored in previous research, especially that which included Indonesian women novelists. 
This eco-criticism study was devoted to uncovering the environmental ethics represented by Indonesian women novelists in their works. The choice of the perspective of environmental ethics was based on the argument that ecocritics is a school of thought that investigates literature in relation to the history of thought, ecology, ethics, and the environment (Hutchings 2007). In the study of the relationship between humans and the environment, Echeverri et al. (2018) identify interdisciplinary fields that can be used as research topics, including attitudes, behavior, innate preferences, perception, and values. Based on the way humans view the environment, Keraf (2010) suggests that the principles of environmental ethics can be a reference for humans in establishing relationships with nature. The fate of the environment is very dependent on the way humans treat it. Human exploitative behavior toward nature and the environment results in environmental degradation and dehumanization that threatens human life itself (Dobrogoszcz 2017).

Environmental ethics are a philosophical dimension that can mediate changes in human exploitative-dominative behavior so that a harmonious relationship with nature can be established. Cooper et al. (2016) suggest that aesthetic and spiritual understanding of the value of nature leads people to develop moral responsibility toward nature. Keraf (2010) identifies the principles of environmental ethics that can encourage human ecological awareness, namely: 1) respect for nature, which means respecting every form of life and every species that inhabits the ecological community; 2) responsibility, that includes all behaviors of taking initiatives, efforts, policies, and concrete actions to maintain nature sustainability; 3) cosmic solidarity, that shows feelings of contempt for nature that holds the same position as living things; 4) affection and care for nature; 5) causing no harm, which means not taking actions that can threaten nature sustainability; 6) living simply and in harmony with nature, that is to utilize nature in sufficient quantities by avoiding consumptive and greedy behavior; 7) justice, that is to provide equal access for each individual and group to participate and determine policies relating to nature; 8) democracy, that includes providing the opportunity for individuals or groups to fight for the interests of the environment and gain access to information; and 9) moral integrity, that is to develop respectable moral attitudes and behaviors to secure the interests of nature. The principles of the environmental ethics were used as a framework to analyze the ecological wisdom found in the novels written by the three Indonesian women.

This research is important to enrich the study of the writer's creative process from an ecocritical perspective. According to Bulfin (2017) the relationship between popular fictions and ecological threats should be investigated to find the pressing challenges facing humanity. The results of the study can provide readers with an understanding of ecocritics in Indonesian novels and thus inspire them to become part of the exploration and inculcation of ecological ethical values through literary works. This is supported by Sone's research $(2014,2015)$ which shows that knowledge, values, and trust in the environment sourced from literary works inspire people's behavior for the conservation and development of a healthy environment. Literarture can play a role of persuasion and act as a tool to influence the audience in establishing relationships with humans and non-humans (Nabulya 2018). Therefore, this study assumes that the environmental ethics represented by the Indonesian women novelists, through their works, can inspire the values and beliefs of their readers.

\section{Methods}

A qualitative-interpretative approach was utilized to reveal the environmental ethics represented in the novels written by Indonesian women (Elliott and Timulak 2005). Descriptions, interpretations, and explanations of ethical values are carried out through thematic analysis (Ignatow and Mihalcea 2018). Therefore, the analysis process in this study used the theories of ecocriticism for the main theoretical orientations. 
This ecocritical study examined three novels authored by Indonesian women writers, Anak Bakumpai Terakhir [The Last Bakumpai Child] by Yuni Nurmalia (2013), Sihir Negeri Pelangi [Magic in the Land of Sand] by Siwi Nurdiani (2012), and Partikel [The Particles] by Dewi Lestari (2012). The selection of the three novels was based on the thought that they contain discussions of ecology as part of creation. Anak Bakumpai Terakhir novel narrates the life of the Dayak Bakumpai tribe who lives on the island of Kalimantan (Borneo). The novel revolves around people who are struggling to maintain their existence from the threat of extinction due to mining and expansion of plantation areas. Kalimantan (Borneo) has been in the world's spotlight due to the exploitation of forests, animals, mining assets, and its natural environment. Sihir Negeri Pelangi relates the story of the struggle of youth in Kulongprogo to defend ecosystems in the South Coast of Yogyakarta from the threat of sand mining. Partikel is a science fiction saga with the background of living ecosystems in Bogor and Kalimantan (Borneo), the two regions that represent the icons of Indonesian or even the world's ecosystem life.

Data in the form of sentences and paragraphs that represented environmental ethics were collected using the quotation reading technique. Each text of the novel was carefully read. The data were then marked and encoded. A guideline containing focus and indicators to support the data collection process was developed. To determine the selected data, critical and reflective repeated readings were conducted.

The data were analyzed using analytical procedures (Miles, Huberman, and Saldana 2014). The analysis began with identifying environmental ethics in a series of sentences and paragraphs in each novel. The identified data were selected, structured, and grouped according to the description of the ethical ideas to be conveyed. The interpretation of the environmental ethics was based on the perspective of researchers in textual and contextual terms with reference to ecocritical theories. The narrative of data presentation was accompanied by a comprehensive explanation. Data that had undergone the verification process were determined as the final conclusions and research findings.

\section{Findings}

The results of the study show that the three novels authored by Indonesian women represent a variety of environmental ethics. Environmental ethics in the novels are represented in the form of respectful attitudes, responsibility, cosmic solidarity, compassion and care, causing non-harm behavior, and democracy.

\section{Respectful Attitude}

"Respect" is a manifestation of respectful behavior in giving treatment to nature. In the novels, the Indonesian women represent this ethic through the characters' actions in maintaining ecological cohesiveness, respecting the life of species, and living in harmony with nature.

\section{Keeping the Ecological Cohesiveness}

Ecological cohesiveness is shown through the behavior of the characters that see nature as part of themselves. The characters put nature and humans in a reciprocal, parallel relation where they need each other. The respect given by humans aims to preserve nature and at the same time protect them from harm.

"Nature and us are one, Zarah. When we believe in nature, nature will protect us. Nature will speak to us in certain languages."

"What language is it, Dad?" I asked.

"The language of sense and the language of sign," he simply answered. $(2012,69)$ 
The characters in the novel represent an appreciation of nature. The father figure in the novel advises his daughter Zarah to connect with nature because nature provides protection. The father interprets the union of human and nature as a result of appreciation to nature or care for nature that can also provide protection for humans. On the contrary, arbitrariness toward nature can make it angry, leading to misery. The arbitrariness meant here is exploitation. The wrath of nature from the father's perspective is realized in the form of a catastrophic attack, such as flood and forest fires. The series of the father's arguments in the above excerpts reflects the equal ecological relationship between nature and humanity who need each other.

In the context of the Indonesian ecosystem, this environmental ethical value has significance for connoisseurs of literature and for the public in general. Indonesia consistently faces problems regarding forest fires and natural disasters every year. Forest fires have even become a consistent problem that has impacts across countries. Likewise, floods continue to occur with increasing casualties. The root of the problem is the exploitative attitude of humans that gradually destroy nature. This topic seems to be central to novels written by the Indonesian women, who would be likely to instill the importance of maintaining ecological cohesiveness.

In Indonesian novels, nature is described as an elemental part of the human body. Natural cohesiveness with humans is shown through natural metaphors where rivers are represented as the breath of human, water as blood, and soil as the place from where human arises. These metaphorical representations show that nature is an inseparable part of human life. This is indicated in the following quote. "Kai once said, "Nature and rivers are the breath of the Barito tribe, water is their blood, and land is from where they arise. That is why they are always furious to see foreigners rummaging through their forest" $(2013,248)$. The ecological relationship between humans and nature seems to be very close. The metaphors used in this novel aim to describe the close relationship between humans and bio-ecosystems. The metaphors "nature and rivers are the breath of the Barito tribe" and "water is their blood" presuppose the position of nature as a vital organ for humans. Human life and death are determined by the existence of that organ. The cessation of blood flow or breath becomes the end of a life. These expressions are a form of warning from the writer who wants to emphasize that the loss of nature is a disaster of life because nature is like blood and breath. Therefore, humans must be able to unite with nature in mutual relationships because nature is an important organ that can ensure human survival. In addition, the metaphor, "land is from where they arise," sends the message that humans actually come from nature.

\section{Respecting Life of Every Species}

Respect toward nature is demonstrated through respect toward ecological living. The novels written by Indonesian women mostly illustrate that the survival of living things is very meaningful to human life. The life of a species is described as having a very important role. The woman authors further describe that the survival of a species can support the survival of other species. The novels outline the struggles of the characters in protecting endangered and rare species, such as fungi. Fungi as a symbol of ethical values give the message to the reader that even the smallest organism has significance for the survival of life on earth. Likewise, the death of one species will threaten the lives of other species.

And not only that, trees in the Jambul Hill are home to dozens or even hundreds of species, including rare fungi that have great potential to save the earth. Just cut one tree in the hill, all the other species will be gone too. Our job, Zarah, is to protect the forest from humans. $(2012,42)$

Zarah is a young girl who was taught to love the life of every living creature. Firas as her father demonstrates "environmental piety" by inviting Zarah, his daughter to preserve the forest. 
Through the expression "Just cut one tree in the hill, all the other species will be gone too," the author wishes to show that every species has a significant impact on other living things. The excerpt from the novel emphasizes the importance of preserving the lives of all species by being respectful toward nature.

\section{Live Harmoniously with Nature}

Nature is an integral part of human life in ecology. Therefore, humans should respect the life of species in nature by providing opportunities for them to live in it, neither by disturbing nor damaging it. The novels written by the Indonesian women highlight the characters' awareness of the importance of living in harmony with nature. In one of the novels, the character named Zarah obtains pleasure and extraordinary spiritual experience directly from nature as an environmental activist. Before she worked as an activist, she only enjoyed the nature through her father, who always reminded her to maintain in harmony with nature. The ethical value represented in this novel sends a message to the reader that life in harmony with nature will bring calm and peace. "We live and throb together. If all this time my father always taught me to live in harmony with nature, I understood the point, only this time I experienced it as a whole. They are no longer words. All the cells in my body can feel it" $(2013,148)$. This excerpt represents a human being who is able to coexist with other ecological components. The quote teaches moral principles to maintain harmony with other ecological communities. Harmony with the ecological community is a manifestation of environmental ethics which views nature as an important part of human life.

\section{Responsibility}

Ethical behavior in the form of responsibility in the novels is shown by the moral awareness of the characters. They acknowledge that the lives of future generations are determined by the sustainability of the ecosystem. Environmental balance is important to pass on to future generations.

Okay, Sir...,Nanang is a coastal boy who still longs for the existence of undisturbed or undamaged natural harmony. I always dream that my grandchildren will continue to be served with the hospitality of the South Coast, as we currently enjoy. The newness burst in my chest when I convince you, and myself, of the love that I had and of the spirit that I kept from fading. $(2012,58)$

It appears that the character in the novel is determined to pass down ecological harmony to future generations. It shows his ecological awareness and responsibility. He has a calling to take care of the universe as a home for all creatures, including the unborn generation. He tries to spread awareness that nature does not only belong to those who live in the present, but also to those who live in the future.

The principle of responsibility also means taking concrete actions to conserve and sustain ecosystems. In one of the Indonesian novels, the responsibility is shown through a character's willingness to volunteer as an orangutan researcher. For the sake of the survival of orangutans who are threatened by forest destruction in Kalimantan (Borneo) due to the opening of mining and plantation land, Inga Dominykas is willing to live in a camp built in the middle of the forest. She dares to cross the continent, leaving behind all the conveniences of city life to care for the orangutans. "Inga Dominykas is a Canadian woman from Lithuania who founded this camp. No human on this planet understands orangutans like Inga Dominykas. Twenty years ago, Ms. Inga and her husband came here as researchers. Before them, there had never been an intensive study conducted on orangutans" $(2012,191-192)$. 
The responsibility shown by the character is the manifestation of ethical behavior by loving members of the ecological community. Animals are members of ecological communities that also need life. Therefore, humans are responsible for protecting it. This is shown through the character of Inga who cares for orangutans. Baby orangutans who lose their mothers are cared for like humans, educated to be independent and then released again to live in their natural habitat. She protects orangutans from the threat of exploitation and trade between countries.

The principle of responsibility is also demonstrated by Eliyana and Chandra, two major figures in Anak Bakumpai Terakhir. The opening of mine land causes severe environmental damage. Rivers and soil are polluted by poisons and chemicals. The life of the island of Borneo is threatened. In fact, humans are also under threat from disease due to pollution. To save the environment, Eliyana conducts an anti-waste campaign directed at mining entrepreneurs.

The mining problem, which is one of the main environmental issues in Indonesia, has taken the attention of Indonesian women writers. In the novels written by these women, the character Eliyana acts as an environmental activist who is actively conducting anti-waste campaigns. She tries to make miners aware of the hazardous effects of cyanide and mercury on human body. Eliyana and Chandra educate the traditional miners and mining companies on how to process metals safely and invite them to reduce waste disposal. The story of Eliyana and Chandra is an example of the Indonesian women writers' strategy to underline the roles and responsibilities of citizens towards the environment. This ethical value sends a message to the reader that each individual can take a significant role in saving the environment.

On the other hand, I focus on an anti-waste campaign and the pollution of cyanide and mercury poisons found in gold mining waste. We also play an active role in the case of reforestation and provide an alternative treatment for heavy metal waste. In front of the mining entrepreneurs, consisting of traditional gold miners and mining entrepreneurs, Chandra campaigned on the issue of waste reduction which is expected to be followed by other residents and companies. $(2013,192)$

The actions taken by the characters in the novel show their responsibility toward the sustainability of the ecosystem by conducting anti-waste campaigns against the community and companies that contribute to polluting the environment. They are carrying out real and direct initiatives to save the threatened ecosystems. The characters' responsible attitude is a resistance to exploitative corporate behavior. This finding correlates with the work of other Indonesian artists as revealed by Jurr s (2018) that the representation of visual art shows the interestof capitalism through production and consumption, which are the main causes of environmental destruction. The works of these artists represent the actions of companies that prioritize production to obtain profits instead of environmental safety. The practice of colonialism and neoliberalism has led to the degradation and destruction of Indonesia's land and air. In the novels written by the Indonesian women, there is a real effort to raise awareness that the continuity of ecological life is more important than mere material benefits. The excerpts from the novel at the same time provide criticism that the companies representing capitalistic groups are indeed a major threat to the safety of the earth.

\section{Cosmic Solidarity}

The principle of cosmic solidarity leads humans to control their behavior from harming nature. In modern Indonesian novels, cosmic solidarity is manifested through customary rules and natural sanctity. Indonesian people uphold their ancestral heritage in the form of customs, including those related to environmental aspects. In the novels written by the Indonesian women, traditional symbols, such as traditional and sacred figures, are used to build cosmic solidarity. 


\section{The Symbol of Integrity and Customary Control}

In Indonesian culture, customary leaders play a key role in organizing life, including the relationship between humans and the environment. Solidarity with nature is demonstrated through the integrity of traditional leaders. In the community, traditional leaders become an important part of the continuation of ecological life. Customary leaders show integrity that is not tempted by material gain. In a novel written by Nurmalia,' a traditional leader, Kai, is portrayed as having a significant role in protecting forest sustainability; he firmly rejects the investors' offers to change the function of the customary forests. His attitude is based on the customary rules which require him to provide protection for the survival of the forest ecosystem. The representation of this ethical value puts an emphasis on the importance of the role of non-formal leaders who have a firm attitude.

Apa explained the rampant exploitation and conversion of our island forests to mining and plantations, making a customary leader like Kai who holds the custom firmly, refusing investors' offers to exploit their customary forests. The refusal to extract wood on a large scale is based on the belief that custom has governed how to use wood in the forest. $(2013,73)$

Kai (a greeting in local language for grandfather) as a traditional leader shows ecological integrity. Kai is not materialistic. He shows determination in preserving nature. Kai dares to reject the temptation of exploitative capitalism by refusing to turn forests into mining land that has high economic value. The environmental ethic expressed by traditional leaders, such as Kai, is an example of cosmic solidarity that can help preserve ecological sustainability.

Cosmic solidarity is also expressed through customary rules. In Anak Bakumpai Terakhir, the longhouse of Dayak Bakumpai is a traditional symbol that holds control over the lives of the community members, including those associated with nature. All decisions related to forest management and forest sustainability are made in Rumah Panjang [Long House]. Land ownership among residents and villages is regulated by customary rules.

Kai was not the only person who opposed the foreigners who "laid their dirty hands" on our native earth, but the traditional leaders from each of our tribes also played an important role in preserving the forests in our home. The long house fights in a huge war in controlling access and ownership of land among residents and villages. $(2013,73)$

In a novel written by Nurmalia' the customary leader is depicted as someone who plays an important role in organizing the relationship between his people and nature. Kai manages how the people can gain access to the land ownership. Kai as a traditional leader believes that land clearing is contrary to customary principles. For Kai, the opening of mining land will damage ecological life. This illustration shows that cultural aspects influence the community awareness of ecology.

\section{Symbols of the Nature Sanctity}

To preserve the life of the ecosystem, the Indonesian women describe nature as a community member who is comprised of supernatural elements. Therefore, there are certain actions that must be avoided by the community members so as not to incur losses. The effort is an ecological protection based on community culture. In one of the novels, the forest is told as an environment that is not touched by humans. Forest sustainability is guaranteed due to the belief of the people who live around it. Forests are depicted as sacred places inhabited by demons. People are terrified of entering the forests because they believe in the existence of the forests' guardians. This condition thus prevents the community members from exploiting the forests. The local people believe that the disturbance to the forest can lead to a disaster. 
"Batu Luhur people must know all about diseases, Brother! They should also recognize that there is no ghost in the Jambul Hill!"

"No Zarah. It's not time yet," Dad replied quickly. "the Jambul Hill should be protected. It is better to leave it like this. As long as people do not dare enter the area, the trees will be left alive. The Guru Mushroom will remain safe." $(2012,40)$

The local community believes in the existence of the supernatural power of the forest. The emergence of fear because of the possibility of natural disasters, illness, or harm if disturbed by community members allow the forests to sustain Thus, it can be used as a tool to provide protection. This is an effort to protect the ecosystem through cultural symbols. The Indonesian women writers try to take advantage of non-physical aspects as a medium for nature protection.

\section{Compassion and Caring}

The principle of environmental ethics is also reflected by the Indonesian women through the love and care for animals. As a component of ecological life, animals receive protection from humans. Affection is given as a reflection of the human perspective that places animals and other ecological communities on a par with humans.

We travel places like conjoined twins. When I take a shower, Sarah takes a bath too. When I eat, Sarah also eats from my plate. She even accompanied me to poop. The only moment Sarah leaves my body is when I change clothes. That can happen as the result of persuading, struggling, forcing, and other various acrobatic movements. Before meeting Sarah, I never imagined that I would have to struggle to change my shirt. $(2012,203)$

That night, I barely slept. I held Sarah tightly. It takes two or three years for her to be independent, I thought. If I go, she will lose her mother again, for the second time. I realize that not all orangutans who live here will be babysit by the same person continuously. There might be some staff who only work for two or three years and after that, they will leave to take care of others. $(2012,203)$

The excerpt above shows that ecosystems are present not only to meet human needs, but also provide life for other living creatures. An ecological community is an important element in human life that must be preserved. In the quote, a baby orangutan, Sarah, whose mother died in hunting accidents has received protection from Zarah, an environmental activist. Sarah grows in Zarah's care. Zarah raises Sarah like a human baby. Sarah is given milk, bathed, and caressed every night by Zarah. Zarah's effort to take care of Sarah is a form of affection for other ecological community members. In this context, Lestari' instills the importance of love and care for all living creatures, including animals.

\section{Causing No Harm}

One of the important environmental ethics is to protect other species to maintain the continuity of their generations. Causing no harm is a reflection of ethical behavior that is demonstrated through wisdom, initiatives, and actions. This ethical attitude is demonstrated through the characters' initiation and action to protect animal and plant species and preserve cultures. The representation of this ethical value is presented below. 


\section{Protecting Every Living Species}

In The Particles, ecological awareness is carried out by caring for community members. Humans also depend on other ecosystem members to survive. In the novel, the main character, Ayah, advises Zarah to struggle to protect the fungus from people who cut down the forest. Ayah is so worried about losing the species if people are given freedom to enter the forest.

"Until forever, Zarah, don't you dare to let them cut down the Jambul Hill. Those who aren't sober are not allowed in"

"I leave all of this to you. You are the heir. You are the guardian of the Jambul Hill and thus of the Guru Mushroom." $(2012,72)$

The quote mandates that each individual has a responsibility to protect the ecosystem community. Environmental awareness needs to be built because not all individuals feel the need to protect nature. It is important for every person to participate in nature conservation. However, due to lack of environmental awareness, some people actually do actions that harm nature.

\section{Preserving the Tribes of the Nation}

The Indonesian novels also express individual responsibility to preserve nature, including human preservation. In Anak Bakumpai Terakhir, the extinction threat to the Dayak Bakumpai tribe is associated with the destruction of the ecosystem. Aruna became the only native woman of Dayak Bakumpai and Avara became a young native of Dayak Bakumpai. The only way to preserve the authenticity of Dayak Bakumpai is by marrying Aruna to Avara. Their marriage has the primary goal of protecting their ethnicity from extinction. This effort is an example of the struggle and sacrifice of Dayak children for the preservation of their tribe.

Eliyana knocked on my forehead. "Of course you have to get married," she said while staring at my innocent face. "To be honest, it will be difficult to get rid of all the heavy metals that have entered the body. But, you have to get married to continue the descent. You need to get married to the descendant of the Bakumpai tribe too." $(2013,248)$

Aruna's involvement in environmental preservation activities has made her aware of the continuity of the Dayak Bakumpai tribe. She realizes that she has to marry Avara to maintain the existence of her tribe. Aruna has to struggle because that awareness cannot be found in Avara because he does not even live in Bakumpai anymore. He had to immigrate to Jakarta to save himself from the threat of poisoning from mining. Aruna thus follows Avara to Jakarta and convinces him to marry her to maintain the existence of their tribe.

Aruna's struggle to marry Avara is not only to grant the wish from Kai, but also to preserve the ecosystem. Aruna has showed tenacity and determination to maintain the authenticity of his tribe. At last, the unity of this couple will become the last hope to sustain the life of Dayak Bakumpai tribe. In this story, Aruna shows one of the moral principles in environmental ethics which is to sustain ecology. Even though they ultimately fail to get married, Aruna has become an inspiration that ecosystem sustainability is worth fighting for.

\section{Being Democratic}

Another principle in environmental ethics is to provide equal access for each individual or group to participate in taking action to preserve ecological life. The Indonesian novels narrate the story of the struggle of the research community and non-governmental organizations in 
nature sustainability. In The Particles, it is told that researchers from various countries come to visit Tanjung Putting to save the orang utans from exploitation and extinction. The researchers play a role in campaigning the animal rescue.

Our activities are indeed repeatable. But in this last camp you will feel the difference. The community here is so lively. Not just tourists who come for a moment and go again. Here there are volunteers, students, researchers from various parts of the world. I felt I was living in a small international village, between nations, between species. $(2012,105)$

The expression of democratic principles in environmental ethics shows that environmental sustainability is a shared responsibility. Policy makers must open public participation and encourage the involvement of all parties. This is shown in the above excerpts, through the attitude of openness to accept volunteers from different countries. The differences are put aside for the sake of orangutan conservation.

\section{Discussion}

The results of the study show that the novels authored by the Indonesian women represent a variety of environmental ethical values. Environmental ethics found in the novels include respect, responsibility, cosmic solidarity, compassion and caring, causing no harm, and democratic attitude. The ethical values expressed in the novels show the perspective of the Indonesian women in addressing ecological issues. In the past, environmental issues in Indonesian literary works used to be placed more as a setting of creation with the revealing of the nature's beautiful and charming conditions. The authors explored the beauty of nature as a writing theme. However, in the novels written by the Indonesian women analyzed in this study, readers' awareness and concern for environmental problems are raised. This can be interpreted as part of the writers' concern about the practice of domination and exploitation that is currently happening. Through their works, the women show how to treat nature appropriately and wisely. The ethical values represented as described in the previous sections are noble behaviors that can lead the reader to have a friendly attitude and live in harmony with nature. This finding is in line with the view of Sone (2015) who argues that the basis for nature sustainability lies in ecocentric human behavior that can only be generated through boosting human awareness of environmental co-existence.

The Indonesian novels also portray the environmental issues faced by the country. The authors describe various environmental problems in their works, namely by mentioning ways humans respond to environmental threats, narratives of disturbed and endangered animals and telling stories about damaged plants and forests and minerals exploited for economic purposes. This finding can be interpreted as the totality and perfection of the pro-environmental attitudes of Indonesian women. The pro-environment attitude in the novel reflects the values, norms, beliefs, and personal attitudes of the author (Everard, Reed, and Kenter 2016). The complete portrait of environmental problems does not occur by accident, but is inspired by the writer's ideology and environmental awareness. According to Adsit (2017), all forms of representation, such as in literature writing, reflect the values, assumptions, and ideology of the writer. Ideology in this context is the perspective used by the writer and the creation of their work. The ethical values of the environment represented in the works of Indonesian women are ideas that are believed and fought for. These are love, affection, care, and responsibility toward nature.

The diversity of ethical values represented in the novels demonstrates the efforts of Indonesian women to shape the perspective of society, especially the readers, on nature sustainability. It appears that the Indonesian women seek to carry out the function of an activist. The novels serve as a medium through which ideology and concerns can be delivered. Ecocritical narratives in novels by Indonesian women function as vehicles that drive social, 
moral, and ethical values (Salisu Barau, Stringer, and Adamu 2016). The findings of this study are in line with the view of Estok (2009) who suggests that ecocritical activism leads to raising awareness, exposing problems, embracing the community, and practicing part of an awareness campaign. Two main aspects that are represented in the novels written by the Indonesian women are the narrative of environmental problems and the environmental awareness-raising efforts to encourage the reader to take a caring attitude toward the environment. Environmental problems are demonstrated through narratives of forest destruction, species extinctions, water and soil pollution, and threats to the survival of animals. The problems arise as a result of human exploitative attitude. Furthermore, the awareness-raising efforts are made by representing values that could change the reader's perspective, such as the narratives to be involved in the role of saving animals, preserving forests, opposing illegal mining, and working collaboratively on environmental love campaigns.

From an ecocritical perspective, it appears that the works of the Indonesian women novelists are mostly influenced by Garrard's eco-criticism theory. Arcadia and Idylls are two of Garrard's (2004) ecocritical concepts that affect the novels. The Arcadia concept is represented through ideal behavior to preserve the forest, peace of animal life, and human relationships with other elements of the ecosystem. In addition, respectful behavior, responsibility, solidarity, compassion, and caring attitude are the idylls concept's representation. The results of this study are in line with the findings by Naidu (2014), which indicate that criminal fictions in South Africa usually discuss environmental ethics. Through this study, it can be seen that Indonesian women writers use their novels as a medium to transform society's ethical attitude towards the environment. They emphasize the importance of abandoning an exploitative attitude to develop a caring attitude towards the universe so that a harmonious relationship between the environment and humans can be created.

The inclusion of the environmental ethics in the novels is proof that Indonesian women writers are the advocates of pro-environment movement. Through their novels, the Indonesian women wish to build a bridge between the realities of social life and the literary world. The target to be achieved is the emergence of environmental awareness for every citizen. This is in line with the views of Murphy (2009) and Tosic (2006) who argue that eco-criticism aims to provide humans with awareness about the world, a sense of personal responsibility, and invite humans to consider the impact of contemporary society on the environment.

This study has confirmed the previous research findings related to women's proenvironment attitudes, such as Braun, Cottrell, and Dierkes (2018), Ramstetter and Habersack (2019), and Barry and Grady (2019). The findings of this study indicate that women writers fight for the sustainability of ecological life and the safety of the earth. The integration of environmental ethics in novels is a manifestation of the ideology of women writers who place environmental problems as an integral part of their lives and works.

The results of this study also show that women writers in developing countries, such as Indonesia, have concerns about environmental issues. The tradition of writing about nature tends to be dominated by Anglo-American writers (Buell, Heise, and Thornber 2011; Sylvia Pasi 2017). However, this study and the study of Sylvia Pasi (2017) on black women writers' works in Africa confirm that the conception of nature in literary works has transcended regional boundaries. Women writers in developing countries can also come out of the domestic zone and voice social political issues. The results of this study become a capital to uncover a broader perspective of women writers on nature and the environment in the East, such as the attitudes of women writers towards government environmental policies and environmental issues that are reflected in their political choices and decisions. 


\section{Conclusion}

The results of this study suggest that the novels authored by Indonesian women represent a variety of environmental ethics. Environmental ethics found in the novels include respect, responsibility, cosmic solidarity, compassion and caring, causing no harm, and democratic attitude. The diversity of environmental ethics found in the novels reflects the writers' knowledge, attitudes, integrity, and ecological awareness. These findings can be interpreted as the totality and perfection of the pro-environmental attitudes of Indonesian women writers. The representation of environmental ethics in the novels also performs the functions of awareness and activism.

The results of this study confirm previous findings about women pro-environmental attitudes. Environmental issues cannot only be claimed by women writers from developed countries, but also women from developing countries who are usually put in a dominated position. These findings provide an opportunity development of broad eco-criticism studies. The results of this study indicate that environmental conservation has become an important issue in the creation of literary works by the Indonesian women. They have shifted the issue from romantic themes to an attempt to explore the topics around environmental problems as a result of human activity. Indonesian women appear to be trying to portray the threat of ecosystems as a result of exploitative behavior and actions. This finding shows that Indonesian women writers prioritize ethical values in overcoming environmental problems.

Further research can be conducted in the field of behavioral studies to measure the impact of these novels on people's attitudes and behavior toward the environment. The findings of Małecki et al. (2018) suggest that fiction can have a real impact on human attitudes toward animals. Behavioral studies are recommended for students to improve their attitudes and behavior toward the environment. Research in the future needs to measure readers' attitudes toward environmental care as an after-effect of reading novels with environmental themes, especially those written by women.

This study, however, involved a limited number of authors and works. Obviously, the three selected novels cannot represent the perspective of all the Indonesian women novelists and their literary works in general. Therefore, further research on women writers and ecocritical studies involving different points of view needs to be done to complement the findings of this study, including the literary works with environmental themes written by women in other developing countries. Other aspects that also require special attention from researchers include environmental health and environmental politics in literary works.

\section{REFERENCES}

Adsit, Janelle. 2017. "The Writer and Meta-Knowledge about Writing: Threshold Concepts in Creative Writing." New Writing $14 \quad$ (3): 304-315. https://doi.org/10.1080/14790726.2017.1299764.

Ahmadi, Anas, Abd. Syukur Ghazali, Taufik Dermawan, and Maryaeni. 2019. "Ecopsychology and Psychology of Literature: Concretization of Human Biophilia That Loves the Environment in Two Indonesian Novels." International Journal of Literary Humanities 17 (1): 47-59. https://doi.org/10.18848/2327-7912/CGP.

Ahmed, Hamoud Yahya, and Ruzy Suliza Hashim. 2015. "Greening of Resistance in Arabic Poetry: An Ecocritical Interpretation of Selected Arabic Poems." 3L: The Southeast Asian Journal of English Language Studies 21 (1): 13-22. https://doi.org/10.17576/3L-2015-2101-02.

Barker, Derek. 2007. "Green Fields: Ecocriticism in South Africa." Journal of the African Literature Association 1 (2): 55-67. https://doi.org/10.1080/21674736.2007.11690046. 
Barry, Fatoumata Binta, and Sue C. Grady. 2019. "Africana Womanism as an Extension of Feminism in Political Ecology (of Health) Research." Geoforum 103 (July): 182-86. https://doi.org/10.1016/j.geoforum.2018.09.024.

Braun, Tina, Richard Cottrell, and Paul Dierkes. 2018. "Fostering Changes in Attitude, Knowledge and Behavior: Demographic Variation in Environmental Education Effects." Environmental Education Research $24 \quad$ (6): 899-920. https://doi.org/10.1080/13504622.2017.1343279.

Buell, Lawrence, Ursula K. Heise, and Karen Thornber. 2011. "Literature and Environment." Annual Review of Environment and Resources 36 (1): 417-440. https://doi.org/10.1146/annurev-environ-111109-144855.

Bhutia, Yodida and Georgia Liarakou. 2018. "Gender and Nature in the Matrilineal Society of Meghalaya, India: Searching for Ecofeminist Perspectives." Journal of Environmental Education 49 (4): 1-8. https://doi.org/10.1080/00958964.2017.1407283.

Bulfin, Ailise. 2017. "Popular Culture and the 'New Human Condition': Catastrophe Narratives and Climate Change." Global and Planetary Change 156:140-146. https://doi.org/10.1016/j.gloplacha.2017.03.002.

Cohen, Michael P. 2004. "Blues in the Green: Ecocriticism under Critique." Environmental History 9 (1): 9-36. https://doi.org/10.2307/3985943.

Cooper, Nigel, Emily Brady, Helen Steen, and Rosalind Bryce. 2016. "Aesthetic and Spiritual Values of Ecosystems: Recognising the Ontological and Axiological Plurality of Cultural Ecosystem 'Services'." Ecosystem Services 21:218-229. https://doi.org/10.1016/j.ecoser.2016.07.014.

Dobrogoszcz, Tomasz. 2017. "The Planet Heals Itself: The Overkill of Homo Sapiens in Contemporary Literature." European Management Journal 35 (6): 722-728. https://doi.org/10.1016/j.emj.2017.07.007.

Echeverri, Alejandra, Daniel S. Karp, Robin Naidoo, Jiaying Zhao, and Kai M. A. Chan. 2018. "Approaching Human-Animal Relationships from Multiple Angles: A Synthetic Perspective." Biological Conservation 224:50-62. https://doi.org/10.1016/j.biocon.2018.05.015.

Egan, Gabriel. 2015. Shakespeare and Ecocritical Theory. Shakespeare and Theory, Vol. 3. London: Bloomsbury Arden Shakespeare.

Elliott, Robert, and Ladislav Timulak. 2005. "Descriptive and Interpretive Approaches to Qualitative Research." In A Handbook of Research Methods for Clinical and Health Psychology, edited by Jeremy Miles and Paul Gilbert, 147-159. Oxford: Oxford University Press.

Erik Larsen, Svend. 2007. "To See Things for the First Time: Before and After Ecocriticism." Journal of Literary Studies $23 \quad$ (4): $341-373$. https://doi.org/10.1080/02564710701786434.

Estok, Simon C. 2009. "Discourses of Nation, National Ecopoetics, and Ecocriticism in the Face of the US: Canada and Korea as Case Studies." Comparative American Studies an International Journal 7 (2): 85-97. http://dx.doi.org/10.1179/147757008X280803.

Everard, Mark, Mark S. Reed, and Jasper O. Kenter. 2016. "The Ripple Effect: Institutionalising pro-Environmental Values to Shift Societal Norms and Behaviours." Ecosystem Services 21:230-240. https://doi.org/10.1016/j.ecoser.2016.08.001.

Finch-Race, Daniel A., and Julien Weber. 2015. "The Ecocritical Stakes of French Poetry from the Industrial Era." Dix-Neuf $19 \quad$ (3): 159-166. https://doi.org/10.1179/1478731815Z.00000000084.

Forns-Broggi, Roberto. 2012. "Ecological Imaginations in Latin American Fiction." Review: Literature and Arts of the Americas 45 (2): 255-256. https://doi.org/10.1080/08905762.2012.719783.

Garrard, Greg. 2004. Ecocrotocism: The New Critical Idiom. New York: Routledge. 
Hatley, Barbara. 1999. "New Directions in Indonesian Women's Writing? The Novel Saman." Asian Studies Review 23 (4): 449-460. https://doi.org/10.1080/10357829908713250.

Hooti, Noorbakhsh, and Amir Ashrafian. 2014. “D. H. Lawrence's St. Mawr: An Ecocritical Study." 3L: The Southeast Asian Journal of English Language Studies 20 (2): 31-42. https://doi.org/10.17576/3L-2014-2002-03.

Hutchings, Kevin. 2007. "Ecocriticism in British Romantic Studies." Literature Compass 4 (1): 172-202. https://doi.org/10.1111/j.1741-4113.2006.00417.x.

Ignatow, Gabe, and Rada Mihalcea. 2018. An Introduction to Text Mining Research: Design, Data Collection, and Analysis. Thousand Oaks, CA: SAGE Publication.

Jackson, Cecile. 1993. "Doing What Comes Naturally? Women and Environment in Development." World Development $21 \quad$ (12): 1947-1963. https://doi.org/10.1016/0305-750X(93)90068-K.

Jurriëns, Edwin. 2018. "Environmental Aesthetics in Indonesian Contemporary Art." Intertwined Ecologies 33 (1): 59-77. https://doi.org/10.1080/09528822.2018.1538037.

Keraf, A. Sony. 2010. Etika Lingkungan Hidup [Environmental Ethics]. Jakarta: Kompas.

Lehnen, Leila. 2020. "Ecocriticism in Brazil: The Wastelands of Ana Paula Maia's Fictions." Romance Quarterly 67 (1): 22-35. https://doi.org/10.1080/08831157.2020.1698888.

Lestari, Dewi. 2012. Partikel [The Particles]. Yogyakarta: Bentang Pustaka.

Lu, Li-Ru. 2017. "Ecocriticism of Nineteenth-Century Taiwan in John Dodd's 'Formosa." International Journal of Critical Cultural Studies 15 (2): 1-8. https://doi.org/10.18848/2327-0055/CGP/v15i02/1-8.

Lustyantie, Ninuk, Nanik Setyowati, and Saifur Rohman. 2019. "Environment and Habitus in Kalimantan Folklore and Papuan Folk Stories Ecocritical Study." Proceedings of the 28th International Conference on Literature: "Literature as a Source of Wisdom," July 11-13, Universitas Syiah Kuala, Banda Aceh, Indonesia, 392-400. http://jurnal.unsyiah.ac.id/ICOL/article/view/14473.

Małecki, Wojciech, Bogusław Pawłowski, Marcin Cieński, and Piotr Sorokowski. 2018. "Can Fiction Make Us Kinder to Other Species? The Impact of Fiction on pro-Animal Attitudes and Behavior." Poetics 66:54-63. https://doi.org/10.1016/j.poetic.2018.02.004.

Michalik, Yvonne. 2015. "Indonesian Women Filmmakers." Indonesia and the Malay World 43 (127): 378-396. https://doi.org/10.1080/13639811.2015.1054139.

Miles, Matthew B., A. Michael Huberman, and Johnny Saldana. 2014. Qualitative Data Analysis: A Methods Sourcebook, 3rd ed. Thousand Oaks, CA: SAGE Publication.

Mishra, Sandip Kumar. 2016. "Ecocriticism: A Study of Environmental Issues in Literature." BRICS Journal of Educational Research 6 (4): 168-170.

Murphy, Patrick D. 2009. Ecocritical Explorations in Literary and Cultural Studies: Fences, Boundaries, and Fields. Lanham, MD: Lexington Books.

Nabulya, Eve. 2018. "When Ecocriticism and Rhetoric Meet: Environmental Persuasion in Terrorists of The Aberdare." Journal of Literary Studies 34 (1): 61-78. https://doi.org/10.1080/02564718.2018.1447869.

Naidu, Sam. 2014. "Crimes against Nature: Ecocritical Discourse in South African Crime Fiction.” Scrutiny 219 (2): 59-70. https://doi.org/10.1080/18125441.2014.950599.

Nurdiani, Siwi. 2012. Sihir Negeri Pasi [Magic in the Land of Sand]. Jakarta: Najah.

Nurmalia, Yuni. 2013. Anak Bakumpai Terakhir [The Last Bakumpai Child]. Jakarta: Penerbit Salsabila.

Ramstetter, Lena, and Fabian Habersack. 2019. "Do Women Make a Difference? Analysing Environmental Attitudes and Actions of Members of the European Parliament." $\begin{array}{lllll}\text { Environmental } & \text { Politics } & 29 & \text { (6): }\end{array}$ https://doi.org/10.1080/09644016.2019.1609156. 
Retnowati, Retnowati, Endang Ernawati, and Akun Akun. 2018. "Ecocriticism Values in The Indonesian Folktale Timun Emas (Golden Cucumber)." Humaniora 9 (2): 221. https://doi.org/10.21512/humaniora.v9i2.4331.

Salisu Barau, Aliyu, Lindsay C. Stringer, and Abdalla U. Adamu. 2016. "Environmental Ethics and Future Oriented Transformation to Sustainability in Sub-Saharan Africa." Journal of Cleaner Production 135:1539-1547. https://doi.org/10.1016/j.jclepro.2016.03.053.

Sone, Enongene Mirabeau. 2014. "Nature in Crisis: An Ecological Construction and Conservation of the Environment in Swazi Oral Literature." South African Journal of African Languages 34 (2): 195-205. https://doi.org/10.1080/02572117.2014.997056. 2015. "Swazi Oral Literature, Eco-Culture and Environmental Apocalypse." Journal of Human Ecology 52 (1-2): 39-49. https://doi.org/10.1080/09709274.2015.11906929.

Sukmawan, Sony. 2018. "Environmental Wisdom in Oral Literature of Arjuna Slopes People." Lingua Cultura 12 (1): 1-7. https://doi.org/10.21512/lc.v12i1.1459.

Sylvia Pasi, Juliet. 2017. "Theorising the Environment in Fiction: Exploring Ecocriticism and Ecofeminism in Selected Black Female Writers' Works." PhD diss., University of South Africa

Tait, Adrian. 2018. "Ecocriticism and Italy: Ecology, Resistance, and Liberation." Green Letters 22 (2): 216-218. https://doi.org/10.1080/14688417.2018.1496668.

Tošic, Jelica. 2006. "Ecocriticism-Interdisciplinary Study of Literature and Environment." Facta Universitatis, Working and Living Environmental Protection 3 (1): 43-50.

Vakoch, Douglas A. 2012. Feminist Ecocriticism: Ecocritical Theory and Practice. Lanham, MD: Lexington Books.

Volkmann, Laurenz, Nancy Grimm, Ines Detmers, and Katrin Thomson, eds. 2010. Local Natures, Global Responsibilities: Ecocritical Perspectives on the New English Literatures. Amsterdam: Rodopi.

Wiyatmi. 2017. "Conquest and Care for the Preservation of Nature and Environment in the Novel Amba by Laksmi Pamuntjak: Study Ecocriticism." Jurnal Humaniora [Humanities Journal] 28 (3): 315-323. https://doi.org/10.22146/jh.v28i3.22285.

Wylie, Dan. 2014. "Ecocriticism and Women Writers by Justyna Kostkowska." Partial Answers: Journal of Literature and the History of Ideas 12 (2): 396-400. https://doi.org/10.1353/pan.2014.0019.

\section{ABOUT THE AUTHORS}

Sultan: Lecturer, Department of Indonesian Language and Literature, Faculty of Languages and Literature, Universitas Negeri Makassar, South Sulawesi, Indonesia

Anshari: Professor, Department of Indonesian Language and Literature, Faculty of Languages and Literature, Universitas Negeri Makassar, South Sulawesi, Indonesia 


\section{The International Journal of Literary Humanities}

is one of ÿve thematically focused journals in the family of journals that support the New Directions in the Humanities Research Network - its journals, book imprint, conference, and online community.

The International Journal of Literary Humanities analyzes and interprets literatures and literacy practices, seeking to unsettle received expressive forms and conventional interpretations. This journal explores these dimensions of the literary humanities, in a contemporary context where the role and purpose of the humanities in general, and literary humanities in particular, is frequently contested.

As well as papers of a traditional scholarly type, this journal invites presentations of literary practiceincluding unpublished literary pieces. These can either be short pieces included within the body of article or if longer, referenced pieces that are readily available in the public domain (for instance, via web link). Documentation of the literary practice in the article should include factors such as contextual explanation, interpretative exegeses, and audience analysis.
The International Journal of Literary Humanities is a peer-reviewed, scholarly journal. 